\title{
BUILDING HUMAN CAPITAL: THE IMPACT OF PARENTS' INITIAL EDUCATIONAL LEVEL AND LIFELONG LEARNING ON THEIR CHILDREN
}

\section{Jakub Fischer, Hana Lipovská}

\begin{abstract}
The aim of this paper is to examine the impact of parents' educational level on lifelong learning of children and relationship between parents' and student' lifelong learning including language skills and computer literacy. This intergenerational transmission, if proven, could influence the investments into the human capital in the long run. We used data from Adult Education Survey 2011 (AES) to test the hypothesis that the parental attained level of education has a significant impact on the initial educational level of their children as well as on their lifelong learning participation. Furthermore, using data from AES, we tested the association between parental educational level and children's language skills and reading activity and between parental non-formal as well as informal education and students' lifelong learning. We have found that the parental effect on lifelong learning participation is slightly weaker than the effect of initial adult's education. Nevertheless, the intergenerational transmission mechanism obviously works. The relationship between parental and students computer literacy is statistically significant, nevertheless weak. As for the nominal and ordinal character of the data, we used mainly the standard statistical methods including nonparametric tests, logit model and correspondence analysis.
\end{abstract}

\section{Key Words}

Human capital, Lifelong learning, Adult Education Survey, Intergenerational transmission, Computer Literacy
University of Economics

fischerj@vse.cz

ARTICLE INFO

Article type

Full research paper

doi: 10.7160/eriesj.2013.060402

Article history

Received: October 24, 2013

Received in revised form: November 22, 2013

Accepted: November 25, 2013

Available on-line: December 31, 2013 


\section{Introduction}

There is no doubt that the level of human capital has an important role at the social and economic development. Many economists and social scientists solve research questions related to human capital and its impact on economy and society: how to measure level of human capital? How to estimate impact of the level (or growth) of human capital to other social and economic indicators? How to forecast future development of human capital?

For the given society, measurement of level of its human capital is a demanding issue. In some studies, measurement of human capital is simplified to measurement of the level education. There are usually two ways (Mazouch, Fischer, 2011): (i) to estimate the share of tertiary-educated people or (ii) to construct an aggregated indicator which is based on the average education level. In these ways, just formal and initial education is considered. Lifelong learning containing both formal and non-formal education is excluded from the analyses.

However, human capital formation is (directly or indirectly) influenced by multiplicity of factors. A neglected but pivotal factor is the parent's attained level of education which is a proxy variable for the family's social background as the source of potential human capital growth.

The importance of lifelong learning had been highlighted even before the Human Capital theory was developed. John Stewart Mill in his Essay on Some Unsettled Questions of Political Economy remarked that theory and practice did not use to be separated in Ancient Greece, when philosophers received their education and formed their character in the midst of active life (Mill, 1844). Recent studies suggest that the level of human capital is closely connected to the level of parent's human capital. According to
Gary Becker (1993), a low level of education passes from parents to children. Parental education even has a significant impact on the college graduation of the children (Sewell and Shah, 1968). Matéjů et al (2009) noticed that the educational aspirations in Czech Republic are highly influenced by the parents' attained level of education. There is substantial evidence that mothers more affect the female learners and fathers the male (e.g. Ermisch and Pronzato, 2010 or Sewel and Shah, 1968). Mazouch and Fischer (2011) pointed out that tertiary educated people more participate in adult education. Finardi et al (2012) mentions studies predicting return on education investments, including the investments in lifelong learning.

The primary hypothesis should consist in the influence of parental education on the adults' lifelong learning. However, there is still a lack of studies dealing with this problem. The intergenerational transmission was verified by Antoni (2011) who confirmed that the parental level of education influences participation in formal and non-formal education in adulthood. On the other hand, parental human capital might improve the children's education not only directly, but also in an indirect way by providing a better environment, social network and family income (Oreopoulos et al., 2003) due to the transmission mechanism of earnings from parents to children (Becker, 1993). The rare longitudinal studies provide a valuable contribution for confirming the long-term impact on adult lifelong learning. Based on the Columbia County Longitudinal Study (1960 - 2002), the researchers suggest, that the level of parental education positively influences the education level or occupation of the adult in his or her middle adulthood (Dubow et al., 2010). Simonová (2009) shows that the character of the intergenerational transmission in the Czech Republic is of a different character due to the character of political development 
after the World War II. During the 20th century the Czech adults reached higher education than their parents, nevertheless the 90s' are connected with the upward educational mobility.

As well as the parents' initial education level impact on their children's life-long learning the relationship between the parental and children's life-long learning can be studied too. The data from AES 2011 allowed us to examine at least how the parental participation in and attitude to non-formal, formal, as well as informal education influences the non-formal and informal education of students. Students are not expected to participate in guided on-the-job training but clearly the majority of students is expected to study languages, take lessons in driving school or take up a musical instrument or go to art classes. Those students life-long learning reflects especially the attitude toward human capital building from the intergenerational transmission point of view.

According to Denny (2011) the impact of the socio-economic family background can be studied on those families where at least one of the parents works as a teacher, as this background can provide children with further information and a better attitude to learning. The teacher-parent has more information about the educational opportunities available and part of the intergeneration transmission can be possibly explained even by genetics.

It is demanding to analyse the relationship between bluecollar parents life-long learning and the non-formal as well as the formal education of their children. Lippincott and German (2007) suggest that many working-class students had been brought up in the belief that knowledge for knowledge's sake is a waste of time. If it is true, then we should expect a lower level of participation in non-formal and informal education among students with blue-collar worker parents ${ }^{1}$.

The aim of this paper is to present some possible ways of improving the estimates of human capital using data on lifelong learning education in the Czech Republic and to illustrate it in some model computations by using the data from the Adult Education Survey (CZSO, 2013). The rest of the paper is organized as follows. We introduce the data and the statistical methods we used. We then present the results of our analysis. Firstly the impact of the parental educational level on the adults' formal education is discussed. Secondly we test the effect of the parental and the children's initial educational level on the participation on the lifelong learning and on the average number of hours spent by the lifelong learning. In the next part the impact of the parental attained educational level on the adults reading is examined. Finally we analyse how the adults' language skills are influenced by the parental educational level.

\section{Materials and Methods}

Our research is based on the data from the Survey on Adult Education AES 2011. This survey was conducted in the Czech Republic in cooperation with Eurostat as the first in a row of regular surveys monitoring adult education across the European Union. The data set consists of 10,190 responses from respondents aged 18 to 69 years. For the purposes of our analysis, we further modified the file: 677 respondents - students and apprentices - were excluded not to distort information about the parental effect, because the highest level of formal education could not

On the other hand, it should be taken in account that if the bluecollar worker's children aged 18-28 study instead of working, it might indicate that education in their household is more valued (possibly including life-long learning). 
be reliably confirmed. Further another 182 respondents who did not set out their parents' education were excluded. The basic data set was of the range $n=9,331$ after these modifications. While data on the highest educational attainment of the respondents was very detailed (classified according to ISCED 97), the highest educational attainment of parents (or guardians) was available only as a very rough division into no more than lower secondary education, upper secondary education and higher education. Despite losing some information, we used this rough division even for the respondents' education level for direct intergenerational comparison. In order to test the influence of parents on the education of the respondent we also created a variable reflecting the highest-education level among the parents. To analyse participation in further adults' education, a dummy variable was used acquiring a value of 1 if the respondent had been formally educated in the previous year, or if he participated in one or more activities of informal education. The total number of hours spent on lifelong education for the last 12 months was calculated as the sum of the number of hours spent on formal education and the number of hours spent on the three non-formal education activities.

The dataset for the second part of our study consists of 582 respondents - student and apprentices aged 18 to 28 years. From the total amount of 677 students and apprentices, those for whom the data on their parents were not available were excluded. The Adult Education Survey 2011 does not implicitly include information about non-formal and informal education of parents, however it includes data on the all family members living in the one household. From all the households students lived in, we have chosen just those, that were classified as singleparent with child(ren) aged under 25 , couple with child(ren) aged under 25 and a couple of single parent with child(ren) aged under 25 and with another person living in the household ${ }^{2}$ We have judged - case by case - the initial education level of the household member(s) who was/were most probably the parent(s) (according to age, job participation etc.), and compared the initial education level of those family members with the stated initial education level of the students' parents ${ }^{3}$. For further analysis, just those respondents of whose parental identity we had no doubt were included into dataset.

More than one-fifth of the student-respondents lived in the single-parent family ( $22 \%$ of all student-respondents). We have developed the dummy variable which acquired a value of 1 if the student lived in the single-parent family. The other dummy variables acquired a value of 1 if (i) at least one of the students' parents worked in 2011 as the teacher or (ii) at least one of the students' parents worked as a teacher or was educated in the field of teacher training and education science. The second of those two variables was introduced to cover even those parents who were not teachers in 2011but who possibly used to teach before 2011 or had at least pedagogical knowledge that could influence students' attitude towards education in their youth. The fourth dummy variable distinguished students with at least one of the parents working as blue-collar workers (skilled agricultural, forestry and fishery workers, craft and related trades workers, plant and machine operators and assemblers and elementary occupations) from those with white-collars parents (armed forces occupations, managers, professionals, technicians and associate professionals and service and sales workers). The last dummy variable distinguished students where at least

\footnotetext{
To cover even those student in the age $26-28$.

Variables HATFATHER and HATMOTHER (Training successfully completed by the respondents parents) were available for most of the respondents, including students.
} 
one parent completed formal education in computer science, computer use and engineering, manufacturing and construction from non-technicians.

We have used the standard statistical methods. Due to the prevailing qualitative variables of nominal or ordinal character, the analysis of variance, the analysis of the binary logit model, nonparametric tests and correspondence analysis were used. For the description of the strength of relationship measured by Cramer's $\mathrm{V}$ following table was used:

\begin{tabular}{|c|c|}
\hline $\begin{array}{c}\text { Cramer's V } \\
\text { value }\end{array}$ & Strength of a relationship \\
\hline$<0.10$ & Very weak \\
\hline $0.10-0.19$ & Weak \\
\hline $0.20-0.29$ & Moderate \\
\hline$>0.30$ & Strong \\
\hline
\end{tabular}

Tab. 1: The adjectives for describing the strength of a relationship according to Botsch (2011)

\section{Results}

This section is divided into four chapters. Firstly we deal with the impact of the parental educational level and their lifelong learning on the adult children and students in terms of the five parts of human capital: the initial educational level, reading, language skills, non-formal and informal learning. Secondly we analyse the relationship between the initial educational level of adults, their participation in lifelong learning and its intensity. In the third part we discuss the relationship between students' family background and their non-formal lifelong learning including the language skills. Last but not least, we study the computer and internet literacy among parents and students.

\section{Parental educational level, their lifelong learning and children's human capital}

Effects of parental educational level on the formal initial education of their children

We find evidence, that the levels of parental education have an impact on the highest education level of the adult. The most influenced are adults who finished tertiary education. On the contrary, the family education background has very weak effect on those who finished upper secondary education. The higher educated are more influenced by the father's education level, mothers have greater impact on the adults with upper secondary education.

\begin{tabular}{|l|c|c|c|}
\hline & \multicolumn{3}{|c|}{ RELATIVE INERTIA } \\
\hline Adults education & mother & father & Higher-educated parent \\
\hline $\begin{array}{l}\text { At most lower } \\
\text { secondary }\end{array}$ & 0.34 & 0.31 & 0.31 \\
\hline Upper secondary & 0.12 & 0.09 & 0.08 \\
\hline Tertiary & 0.54 & 0.59 & 0.61 \\
\hline
\end{tabular}

Tab. 2: Impact of parents' education on the adult educational level

A symmetric correspondence analysis map (Fig. 1) clearly shows the intergenerational transmission between a parent who reached the highest level of education and the adult. Tertiary education of children is obviously closely connected to the tertiary education of the more educated parent. The same relationship was discovered between upper-secondary educated adults and parents up to the upper-secondary level. 


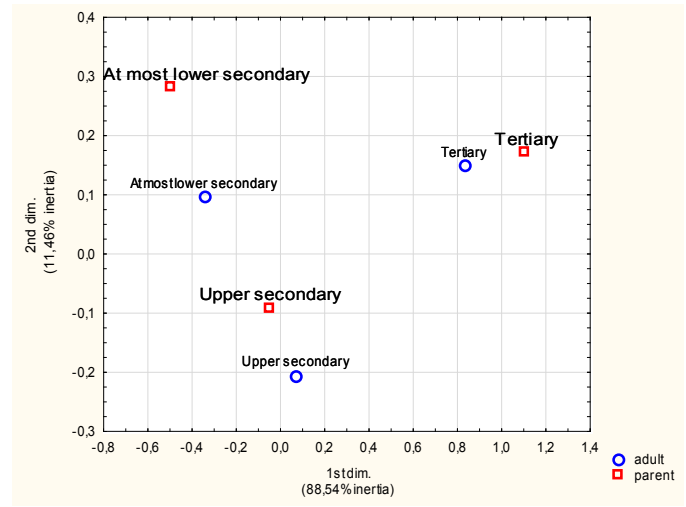

Fig. 1: Symmetric correspondence analysis map - the relationship between parental and adult children's educational level

According to Cramér's V, the more appropriate proxy variable of potential human capital is the educational level of the higher educated of the parents (Cramér's V $=0.32$ ).

\begin{tabular}{|c|c|c|c|c|}
\hline & \multicolumn{2}{|c|}{ MALES } & \multicolumn{2}{c|}{ FEMALES } \\
\cline { 2 - 5 } & FATHER & MOTHER & FATHER & MOTHER \\
\hline Cramér's V & 0.31 & 0.26 & 0.31 & 0.32 \\
\hline
\end{tabular}

Tab. 3: Association between parental educational level and ducation level of males and females

The effect of the parental educational level on the adults reading

Parental educational level has the significant impact on non-readers and on those who read at least 10 books a year. Significantly greatest readers are children of tertiary-educated parents on the contrary the modest readers are children of at most lower secondary-educated parents. According to Cramér's $\mathrm{V}$, the parental effect is stronger for men than for women.

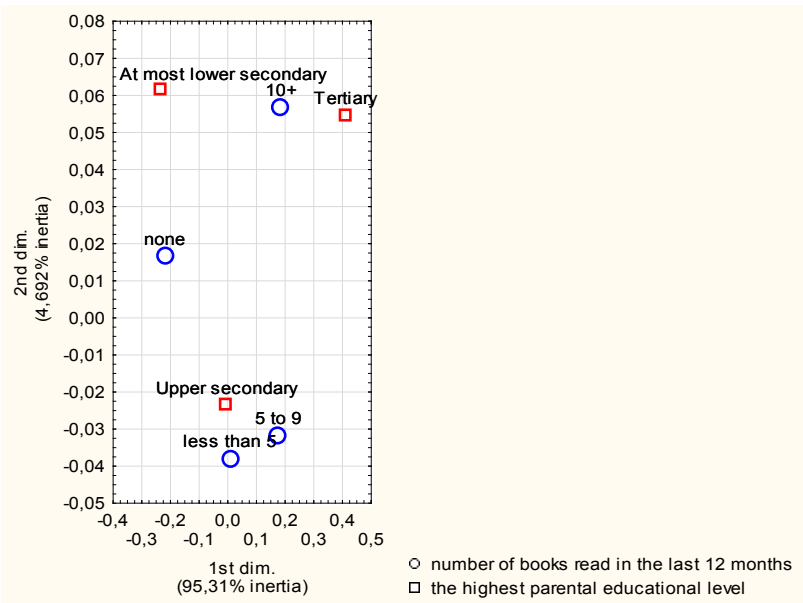

Fig. 2: Number of books read during a year and the highest parental educational level

The more adults read in their free time, the more hours they spend on the lifelong learning. Those who read at least 10 books a year study more intensively in comparison with those who read at most 4 books a year.

The effect of the parental educational level on the adults' language skills

We have discovered a strong correlation between adults' educational level and the number of foreign languages he or she speaks (Cramér's $\mathrm{V}=0.38$ ), the parental educational level has a similar, though weaker, positive effect. While children of, at the most, lower secondary-educated parents speak on 
average 0.6 languages, children of tertiary-educated parents know on average 1.75 languages. The level attained of the bestknown language is again higher for adults whose parents are higher educated. $57 \%$ of AES respondents, whose parents are at most lower secondary-educated, speak no foreign language in comparison to only $8 \%$ amongst the children of tertiaryeducated parents - more than half of whose children speak English as their first foreign language.

The effect of parental life-long learning on the students' nonformal and informal education

Using the $\chi^{2}$ test the relationship between student's participation in the non-formal education and the parental participation on nonformal education has been proven $(p$-value $=0.03)$. The relationship between students' and parental participation in non-formal education exists. If at least one of the parents takes part in non-formal education, the student tends to participate in non-formal education as well. Surprisingly enough, there is no strong effect on the students' nonformal education, if both parents participate in non-formal education $(\mathrm{p}$-value $=0.34)$. The same relationship was proved to be valid also for the parental and students' informal learning: if one of the parents participates in informal education, the student is more likely to educate himself of herself informally.

\section{Lifelong learning in the light of the adults' and parental educational level}

\section{Effects of adults initial education level and parental educational}

\section{level on the participation on the lifelong learning}

Using $\chi^{2}$ test the relationship between educational level and lifelong education of and adult and his or her further education was proved (Cramér's V $=0.33$ ) The impact of parents is weaker (Cramér's V $=0.23$ for fathers and 0.25 for mothers).
This relationship is confirmed by the logit model. The adults with a higher initial educational level will participate in further education with higher probability of $14.7 \%$. Ceteris paribus the tertiary-educated will study during adulthood with an almost $30 \%$ higher probability than at most lower secondary-educated. Higher parental education also increases the probability of further education, however the effect is substantially lower $(3.9 \%-5.1 \%)$. The adult's household income has the same modest positive impact. Age has a negative effect, which was revealed that the older the adult is, the lower the probability of participation in further education.

The difference between the impact of adults' and parental education level on lifelong learning may be caused even by legislation as well as by the type of adult occupation. Further education is obligatory e.g. for health workers (including nurses) or teachers. Many blue-collar jobs are on the other hand connected not only with permanent job training, which considerably increases the level of workers' human capital, but also with obligatory work-safety training or regular qualification certification.

\begin{tabular}{|l|c|c|c|c|}
\hline \multicolumn{5}{|c|}{$\begin{array}{c}\text { Dependent variable: Participation on the lifelong learning } \\
\text { Correctly classified } 71.7 \% \text { cases }\end{array}$} \\
\hline & $\begin{array}{c}\text { Parameter } \\
\text { estimate }\end{array}$ & SE & $\begin{array}{c}\text { Marginal } \\
\text { effect }\end{array}$ & \multicolumn{2}{|c|}{ p-value } \\
\hline Const. & -1.75671 & 0.156084 & & $2.19 \mathrm{e}-029^{* * *}$ \\
\hline Father & 0.246609 & 0.058954 & 0.051 & $2.88 \mathrm{e}-05^{* * *}$ \\
\hline Mother & 0.189626 & 0.058899 & 0.039 & $0.0013^{* * *}$ \\
\hline Adult & 0.708096 & 0.035976 & 0.147 & $3.07 \mathrm{e}-086^{* * *}$ \\
\hline Age & -0.0350732 & 0.001898 & -0.007 & $3.18 \mathrm{e}-076^{* * *}$ \\
\hline Income & 0.100241 & 0.008753 & 0.021 & $2.32 \mathrm{e}-030^{* * *}$ \\
\hline
\end{tabular}

Tab. 4: Logit model 
It is the highest level of parental education that influenced the choice of adult's work. Almost $60 \%$ of AES respondents whose parent were at most lower-secondary educated are economically inactive or unemployed. The proportion of unemployment amongst the children of tertiary-educated parents is significantly lower in comparison with the lower-educated parents (at a $5 \%$ significance level). A blue-collar job is undertaken by $6 \%$ of adults with lower-educated parents, which is significantly more than among children of upper secondary-educated (3\%) and tertiary educated (1\%). Adults, whose parents are tertiaryeducated, are concentrated in business and administration, research and development or education. They tend to work as health workers, clerk or executives.

Those results lead us to the conclusion that the effect of parental education level on adult education might be distorted due to the obligatory training.

\section{The effect of the adults' initial educational level on intensity of lifelong learning}

We have tested the intensity of adults' further education (measured by number of hours spent on formal and non-formal education during 12 months) depending on the level of initial education. Analysis of variance has shown that adults with higher initial education tend to spend more time on lifelong learning in comparison with lower-educated adults. The same is also true for the children of higher-educated parents.

Figure 3 shows that tertiary-educated adults spent significantly more time on lifelong learning irrespective of their parents' educational level. Sons of more educated parents study in their adulthood more in comparison with sons of lower-educated parents, and the same is true for females. However, daughters of upper secondary-educated parents study significantly more hours in comparison with their sons. The difference among sexes in the number of hours vanishes in the case of children of tertiary-educated parents on the one hand and of lowest secondary-educated parents on the other hand.

The higher-educated parent's children tend to live in higher income households: the difference between the household of adults, whose parents are tertiary-educated and whose parents are at most lower secondary educated is nearly of 3 deciles.

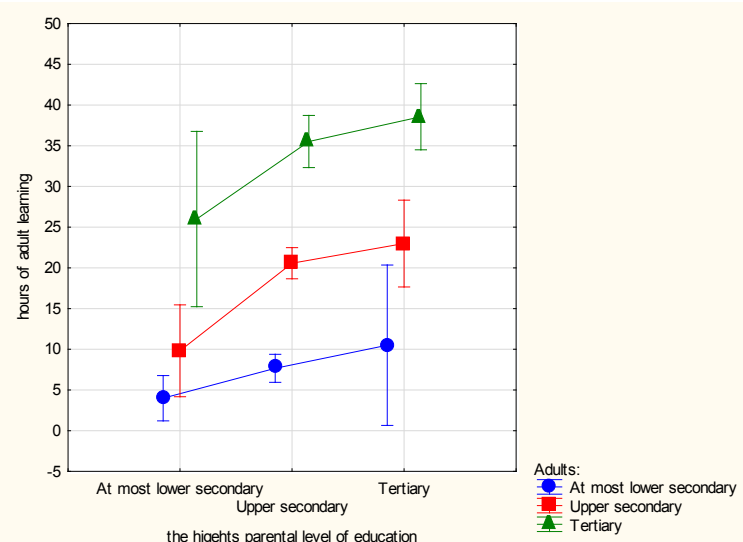

Fig. 3: Association between educational level and hours of lifelong learning 


\section{The relationship between students' family background and their non-formal lifelong learning}

Non-formal education among the students from complete and single-parent families

According to the analysis of variance results there was no significant impact of the family status (in terms of complete or single-parent family) on the students' non-formal education ( $p$-value of the Scheffe test was 0.98). The same result (based on the $\chi^{2}$ test) is valid even for the family status impact on the students' informal education ( $\mathrm{p}$-value $>0.05$ ).

\section{Teachers' children and their life-long education}

We did not prove the difference between the life-long learning participation among the group of students whose parents work as teachers and those whose parents do not work in education ( $p$-value of $\chi^{2}$ test $=0.13$ ). The same is true also for the intensity of non-formal education (measured in hours spent on nonformal education during one year). Those results changed significantly if the teachers' influence included also the children, whose parents had at least pedagogical knowledge. The initial education field served here as the proxy for the pedagogical approach of parents. In this case, based on the $\chi^{2}$ test, a significant impact of teachers-parents was discovered. Teachers' children participated more often in the life-long learning than children whose parents do not have teaching experience. This group of students even read significantly more than their fellow-students from non-teacher households.

\section{Non-formal education of blue-collar workers' children}

Using the $\chi^{2}$ test it was proven that children from the working class participate in the non-formal education less often than the white-collar parents' children $(p$-value $=0.03)$. Furthermore, those children have lower language skills than children from white-collar families in terms of the number of languages known as well as of the language-skills level ( $p$-value of Scheffe test $=0.016$, see figure 4 ).

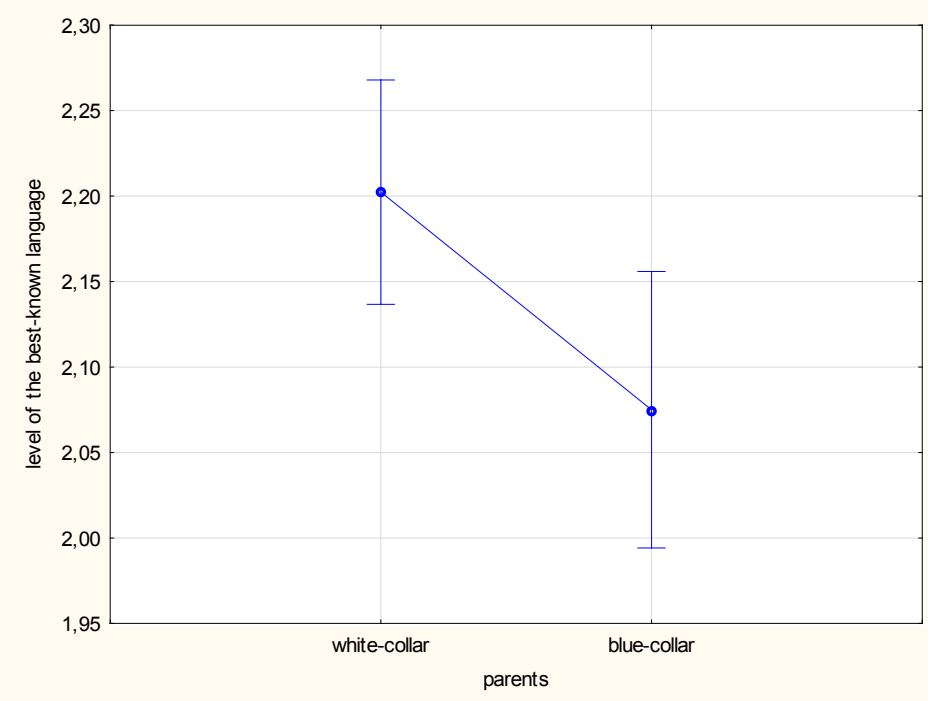

Fig. 4: Difference in the level of the best known foreign language among children from blue-collar and white-collar households respectively

\section{Computer literacy among parents and students}

Computer and internet skills are nowadays widely gained through informal or non-formal education, as the prevailing method is trial and error (compare Durmuş and Kaya, 2010). The Adult Education Survey dataset contains information on the basic as well as intermediate skills (see table 4 ). 


\begin{tabular}{|c|c|}
\hline Computer skills & Internet skills \\
\hline $\begin{array}{l}\text { Copying or moving file or } \\
\text { folder. }\end{array}$ & $\begin{array}{l}\text { Using a search engine to find } \\
\text { information (e.g. Google). }\end{array}$ \\
\hline $\begin{array}{l}\text { Duplicate or move information } \\
\text { within a document. }\end{array}$ & $\begin{array}{l}\text { Sending e-mails with attached } \\
\text { files (e.g. documents or pictures). }\end{array}$ \\
\hline $\begin{array}{l}\text { Using basic arithmetic formulas } \\
\text { in a spread sheet. }\end{array}$ & $\begin{array}{l}\text { Newsgroups or an online } \\
\text { discussion forum (e.g. on websites } \\
\text { for social networking). }\end{array}$ \\
\hline Compressing or zipping files. & $\begin{array}{l}\text { Using the Internet to make } \\
\text { telephone calls. }\end{array}$ \\
\hline $\begin{array}{l}\text { Connecting and installing new } \\
\text { devices, e.g. a modem. }\end{array}$ & $\begin{array}{l}\text { Using peer-to-peer file sharing for } \\
\text { exchanging movies, music, etc. }\end{array}$ \\
\hline $\begin{array}{l}\text { Transferring files between } \\
\text { computer and other devices } \\
\text { (from digital camera or from/ } \\
\text { to mobile phone, MP3/MP4 } \\
\text { player). }\end{array}$ & Creating a web page. \\
\hline $\begin{array}{l}\text { Installing a new or replacing an } \\
\text { old operating system. }\end{array}$ & $\begin{array}{l}\text { Uploading text, games, images, } \\
\text { film or music to websites (e.g. to } \\
\text { websites for social networking - } \\
\text { e.g. Facebook, Youtube). }\end{array}$ \\
\hline $\begin{array}{l}\text { Creating electronic } \\
\text { presentations with presentation } \\
\text { software (e.g. slides), including } \\
\text { e.g. images, sound, video or } \\
\text { charts. } \\
\end{array}$ & $\begin{array}{l}\text { Modifying the security settings of } \\
\text { internet browsers. }\end{array}$ \\
\hline $\begin{array}{l}\text { Writing a computer } \\
\text { program using a specialised } \\
\text { programming language. }\end{array}$ & \\
\hline
\end{tabular}

Tab. 5: Computer and internet skills (source: AES 2011 questionnaire)
Based on then $\chi^{2}$ test, there was statistically significant relationship between parental and students computer and internet literacy ( $p$-value $<0.05)$. Nevertheless, this relationship was according to Cramer's V (table 6) weak.

\begin{tabular}{|c|c|c|c|c|c|}
\hline \multicolumn{2}{|c}{} & \multicolumn{2}{c|}{ PC Literacy } & \multicolumn{2}{c|}{ Internet Literacy } \\
\cline { 3 - 6 } \multicolumn{2}{|c|}{} & Father & Mother & Father & Mother \\
\hline \multirow{3}{*}{ Student } & PC Literacy & 0.18 & 0.16 & 0.17 & 0.14 \\
\cline { 2 - 6 } & Internet Literacy & 0.18 & 0.16 & 0.17 & 0.17 \\
\hline
\end{tabular}

Tab. 6: Cramer's V for the relationship between parental and students' computer and internet literacy

The relationship between students computer literacy and parental participation in the non-formal education was moderate (Cramer's $\mathrm{V}=0.22$ ), nevertheless the relationship between students' internet literacy and parental participation in the non-formal education was statistically significant, but weak (Cramer's V = 0.15).

According to the Analysis of Variance, there is no significant relationship between the social background of students and their computer literacy (children of blue-collar parents do as well as children of white-collar parents). Children, whose parents are technicians, do not have a significantly higher level of computer literacy in comparison with children, whose parents are not technicians.

Histograms (figure 5) clearly shows students do much better in computer and internet literacy in comparison with their parents. 


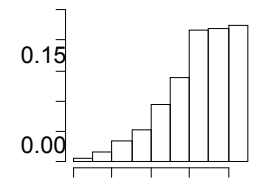

$\begin{array}{lllll}0 & 2 & 4 & 6 & 8\end{array}$

PC score students

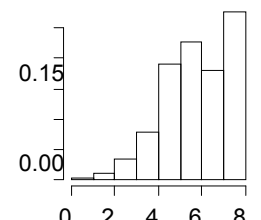

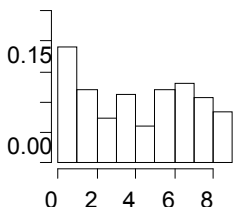

$\begin{array}{lllll}0 & 2 & 4 & 6 & 8 \\ P C & \text { score fathers }\end{array}$

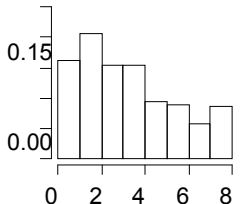

Internet score fathers

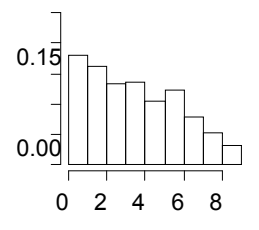

$\mathrm{PC}$ score mothers

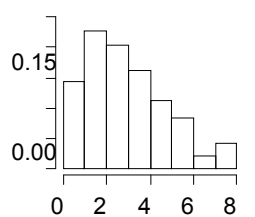

Internet score mothers
Fig. 5: Histograms show the proportion of students, their fathers and mothers, and their achievements on a scale from 0-9 in computer literacy and 0-8 in internet literacy.

\section{Discussion}

Like Ermisch, Pronzato (2010) and Sewel, Shah (1968) we have tested this intergenerational transmission categorized by the sex of parents and adults. Based on Cramer's V we have confirmed the higher impact of fathers on sons and higher impact of mothers on daughters. Notable is the fact, that females are influenced by both parents to a nearly equal extent.

Our findings on the relationship between parental and adults' initial educational level are in line with the results of Antoni
(2011) who stressed the indirect parental impact on the adult's lifelong learning. Parents' education directly influences the initial level of adults' formal education, the impact on other human capital building is a result of more forces.

There is a clear impact of the initial level of adults (as well as their parents) on life-long education. This finding is consistent with the results of a pilot Adult Education Survey 2007 (Mazouch, Fischer, 2011). Even those Czech adults whose parents reached a higher initial educational level, tend to live in families with a higher household income. This is entirely consistent with Becker and Tomes's model of transmission (1994).

Khan (2007) points out that human capital in the form of a sound education and multiple language skills is for the developing economy a competitive advantage. Without any doubt, it is language skills that are, for a small open economy like the Czech Republic, of vital importance. The relationship between the higher educational level of parents and better language skills of children is clearly a crucial contribution for the long-term stock of human capital in the Czech Republic.

Findings on non-formal education in complete and singleparent families are rather unexpected: Pavlát (2011) claims, that students from divorced ${ }^{4}$ families do worse at school and reach a lower educational level. One of the leading reasons for this presumption is the significantly lower household income of the single-parent families. As for the single-mother families, the lower educational level of their children could be

\footnotetext{
$\overline{4}$ Clearly not all single-parent families are based on divorce according to Hasmanová Marhánková (2011) the other types of single-parent families are families of single mothers or of families of widow/widower with child (this last type is nowadays marginal). About $45 \%$ of single-parent families exist due to divorce, one quarter create families with a single-parent, who is de iure still married, but de facto lives alone and the third most frequent are families with single mother or marginally even single father (NCSO, 2005).
} 
influenced even by the significantly lower educational level of single mothers (Hasmanová-Marhánková, 2011). How could the indifference in non-formal education between students from complete and single-parent families be explained? The most likely explanation lies in the structure of the non-formal activities - for example the driving school or language courses are attended by both groups of students.

Our findings on life-long learning confirm the findings of Denny (2011) on the initial formal education. The socio-economic background is obviously of great importance in terms of the human capital. Thanks to the higher educational experiences and probably better availability of books in the household (for example in comparison with blue-collar worker households) the teachers' children have from the very beginning a higher chance to improve their formal as well as non-formal and informal educational level.

Results for the children from working-class background are in accordance with Lippincott and German findings (2007) as well as with the social background hypothesis of Denny (2011). The lower level of life-long learning and language knowledge can be influenced by a lower household income. The role of information, knowledge and additional skills is possibly not so highly appreciated in blue-collar households (e.g. in comparison to the teachers' households or even the white-collar households). Students from blue-collar families face even the lack of educational opportunities.

In accordance with Dincer (2012) we have found, that the computer (and internet) literacy of students is far more advanced than their parents' computer skills. According to Dincer's Pearson product- moment correlations test ${ }^{5}$, relationship between students' ${ }^{\prime}$ and parental computer literacy is positive, but low $(\rho=0.3, p<0.01)$. This result is similar to our $\chi^{2}$ test.

\section{Conclusion}

Previous studies have shown the effect of the initial educational level on lifelong education. This paper provides new evidence of human capital intergenerational transmission. We find that the parental educational level influences the participation in activities of formal and non-formal education in adulthood, its intensity and also the household income of the participant family. Female adults are significantly more influenced by the educational level of their mothers. On the other hand, fathers have a more significant impact on male adult educational level. While recent papers study just the relationship between sexes, we find that Czech adults are most influenced by those of the parents who reached the higher educational level. That might be due to the specific development in the Czech Republic.

The adults who live in the household with higher income are more likely to participate on the lifelong learning. On the contrary the older people are less likely to take part in the lifelong learning. The parental educational level is also interconnected with the branch of the respondents' occupations as well as his or her language skills and reading activity.

The relationship between the non-formal and informal education of parents and students reflects the importance of the socio-economical background. Teachers' children participate more in life-long education (e.g. in terms of book-reading or laguage knowledge), children of blue-collar workers miss the educational opportunities. In the Czech Republic, with

Dincer lead his survey in six Turkish cities, it would be valuable to compare our results with western or central European countries. 
its specifically high divorce rate, children from single-parent families do not seem to participate in the life-long learning less than their counterparts from complete families.

The parents' attained level of education has both direct and indirect effect on the development of individual human capital. Investment in human capital has therefore not only mediumterm effect but via the intergenerational mechanism build establishes an important competitive advantage in the long run.

\section{References}

Antoni, M. (2011), 'Lifelong learning inequality? The relevance of family background for on-the-job training', IAB-Discussion Paper, 9/2011, Nuremberg.

Becker, G. S. (1993) Human Capital: A Theoretical and Empirical Analysis with Special Reference to Education, London: The University of Chicago Press.

Botsch. Chapter 12: Significance and Measures of Association. [online]. 2011 Dostupné z: http://www.usca.edu/polisci/apls301/ Text/Chapter\%2012.\%20Significance $\% 20$ and $\% 20$ Measures $\% 20$ of $\% 20$ Association.htm.

Denny, K. (2011), 'Do Teachers' Children Do Better At School?', Regional and Sectoral Economic Studies, vol. 11, no. 3, pp. 119-134.

Dincer, S. (2012), 'A study of the relationship between pupils and parent's computer literacy level and use', Procedia Social and Behavioral Sciences, vol. 46, pp. $484-489$.

Dubow, E. F. et al. (2009), 'Long-term Effects of Parents' Education on Children's Educational and Occupational Success: Mediation by Family Interactions, Child Aggression, and Teenage Aspirations', Merrill Palmer Quarterly-Journal of Development Psychology, vol. 55, no. 3, pp. $224-249$.
Durmuş, A. and Kaya, S. (2010), 'Education faculty students' preferred learning situation about computer literacy', Procedia Social and Behavioral Sciences, vol. 2, no. 2, pp. 4576 - 4580.

Ermisch, J. and Pronzato, Ch. (2010) 'Causal Effects of Parent's Education on Children's Education', ISER Working Paper Series.

Finardi, S. et al. (2012), 'Returns on private investment in education and fair tuition fees estimates: the case of the Czech Republic', Proceedings of the 9th International Conference on Efficiency and Responsibility in Education (ERIE 2012), Prague, pp. 113-119.

Hasmanová Marhánková, J. (2011) Matky samoživitelky a jejich situace $v$ České republice [Single mothers and their situation in the Czech Republic], Gender studies.

Lippincott, J. A. and German, N. (2007) 'From Blue collar to ivory tower: Counselling first-generation, working class students.' Special populations in college counselling: A handbook for mental health professionals, Alexanria, VA: American Counseling Association, pp. 89-98.

Matějů, P. at al. (2009), 'Student Financial Aid and Inequalities in Access to Higher Education in the Czech Republic and the Netherlands', Sociologický časopis/Czech Sociological Review, vol. 45, no. 5, pp. $993-1031$.

Mazouch, P. and Fischer, J. (2011) Lidský kapitál - měřní, souvislosti, prognózy [Human capital - measuring, context, prognosis] Prague: C. H. Beck.

Mill, J. S. (1844) Essays on Some Unsettled Questions of Political Economy (Essay V), London: Longmans, Green, Reader and Dyer. 
Národní centrum sociálních studií (2005) Sociodemografická analýza neúplných rodin s nezletilými dětmi v ČR [Socio-demographic analysis of single-parent families with dependent children in the Czech Republic], no. HR135/05.

Oreopoulos, P. et al. (2003), 'Does human capital transfer from parent to child? The intergenerational effects of compulsory schooling', NBER Working Paper.

Pavlát, J. (2011) 'Dlouhodobé následky rozvodu pro děti.' [Longterm Consequences of Divorce] Česká a slovenská psychiatrie, vol. 107, no. 5, pp. 297-300.

Sewell, S. and Shah, V. P. (1968) 'Parents' Education and Children's Educational Aspirations and Achievements ', American Sociological Review, vol. 33, no. 2, pp. 191 - 209.

Simonová, N. (2009), 'Proměny v mezigeneračním přenosu dosaženého vzdělání v České republice v historické perspektivě [Shifts in the Intergenerational Transmission of Education in a Historical Perspective in the Czech Republic], Sociologický časopis/Czech Sociological Review, vol. 45, no. 2, pp. 291 - 313. 